\title{
FGFR2 Gene Fusion Positive
}

National Cancer Institute

\section{Source}

National Cancer Institute. FGFR2 Gene Fusion Positive. NCI Thesaurus. Code C153237.

An indication that a FGFR2 fusion gene has been detected in a sample. 